Vol. 2 | No. 2 | 2021 | Hal. 147-150

\title{
PEMBELAJARAN TAMAN PENDIDIKAN AL-QUR'AN DALAM MENINGKATKAN KUALITAS BACA TULIS AL-QUR'AN ANAK
}

\author{
Bahroin Budiya, Roudhotul Jannah, Siti Ani Masruroh, Ilvi Nurdiyanah, Ossy Chandra \\ Destian, Yugi Carol Pratiwi, Diana Haris Mayansari A, Intan Cahyaning Ati, Weny Tri \\ Utaminingsih
}

Fakultas Agama Islam, Universitas Islam Malang

*korespondensi email: bahroinbudiya@unisma.ac.id

\begin{abstract}
ABSTRAK
Dusun Tomporejo yaitu sebuah dusun yang terletak di Desa Dengkol, Kecamatan Singosari, Kabupaten Malang merupakan sebuah daerah dimana sebagian besar mata pencahariannya yaitu sebagai petani dan peternak terutama sapi. Dusun ini memanglah memiliki potensi sumber daya alam yang besar. Akan tetapi, pada sumber daya manusianya masih ditemukan banyak sekali anak-anak yang masih kesusahan dalam memahami ilmu mengenai baca tulis Al-Qur'an karena orang tua disibukkan dengan mata pencahariannya dari pagi hingga malam sehingga kurang memantau perkembangan sang anak serta pandangan sebagian besar orang tua di Dusun Tomporejo bahwa mengaji adalah prioritas kesekian. Maka dari tu, TPQ memiliki peran yang sangat besar untuk mengajak anak-anak mengerti dan memahami pentingnya pendidikan baca Tulis Al-Qur'an. TPQ merupakan sebuah lembaga pendidikan non formal yang membelajarkan peserta didiknya di bidang keagamaan seperti baca tulis AlQur'an, ilmu fiqih dan lain sebagainya. Penelitian ini ditujukan untuk mengetahui : (1) Pelaksanaan Pembelajaran Baca Tulis Al-Qur'an Di TPQ Raudlatul Abror Dusun Tomporejo, Desa Dengkol, Kecamatan Singosari, (2) Faktor Pendukung dan Penghambat Proses Pembelajaran Baca Tulis Al-Qur'an Di TPQ Raudlatul Abror Dusun Tomporejo, Desa Dengkol, Kecamatan Singosari. Metode yang digunakan peneliti dalam melakukan penelitiannya yaitu dengan menggunakan metode Participatory Active Research (PAR) dimana sumber data yang digunakan yaitu obsercasi dan dokumentasi..
\end{abstract}

Kata Kunci: taman pendidikan; baca tulis; qur'an

\section{PENDAHULUAN}

Dusun Tomporejo merupakan sebuah dusun yang terletak di Singosari yang mana di dusun ini sebagian warganya bermata pencaharian sebagai petani maupun peternak. Dikarenakan pekerjaannya yang berlangsung hingga sore hari sehingga para orang tua kurang memerhatikan pendidikan anaknya dan lebih mementingkan pendidikan mata pelajaran umum melainkan keagamaan seperti baca tulis Qur'an dll sehingga masih banyak sekali ditemukan anak-anak yang masih belum fasih dalam membaca ataupun menuis AlQur'an. Maka dari itu, TPQ atau yang biasa disebut sebagai Taman Pendidikan AL-Qur'an ini dibentuk dalam format pendidikan semi formal dimana di TPQ tidaklah mengajarkan baca tulis Al-Qur'an melainkan pendidikan umum selayaknya di Sekolah Dasar (Aristanto et al., 2020; Malik, 2013). Di TPQ jugalah anak-anak Dusun Tomporejo mengikuti proses pembelajaran baca tulis Al-qur'an. 
Pembelajaran adalah proses interaksi peserta didik dengan pendidik dan sumber belajar pada suatu lingkungan belajar (Arifin \& Tamrin, 2019; Suhartoyo et al., 2020; Zakaria et al., 2019). Pembelajaran merupakan bantuan yang diberikan pendidik agar dapat terjadi proses perolehan ilmu dan pengetahuan, penguasaan kemahiran dan tabiat, serta pembentukan sikap dan kepercayaan pada peserta didik. Dengan kata lain, pembelajaran adalah proses untuk membantu peserta didik agar dapat belajar dengan baik. Salah satu pengertian pembelajaran dikemukakan oleh Gagne (1977) yaitu pembelajaran adalah seperangkat peristiwa-peristiwa eksternal yang dirancang untuk mendukun beberapa proses belajar yang bersifat internal.

Taman Pendidikan Al-Qur'an (TPA/TPQ) merupakan lembaga atau kelompok masyarakat yang menyelenggarakan pendidikan nonformal jenis keagamaan Islam yang bertujuan untuk memberikan pengajaran membaca Al-Qur'an sejak usia dini, serta memahami dasar-dasar Dinul Islam pada anak usia taman kanak-kanak, sekolah dasar atau madrasah ibtidaiyah atau bahkan lebih tinggi. TPA/TPQ setara dengan RA dan taman kanakkanak (TK), dimana kurikulumnya ditekankan pada pemberian dasar-dasar membaca AlQur'an serta membantu pertumbuhan dan perkembangan rohani anak agar memiliki kesiapan dalam memasuki pendidikan lebih lanjut (Muntoha et al., 2015; Suyitno, 2018). Tujuan dalam kegiatan ini untuk mengetahui peran TPQ Raudlatul Abror terhadap kualitas baca tulis Al-Qur'an anak di Dusun Tomporejo, Desa Dengkol Kecamatan Singosari.

\section{METODE}

Pengabdi dalam proses pendampingan di Dusun Tomporejo yaitu dengan menggunakan metode participatory active research atau yang biasa disebut dengan PAR. Menurut Agusta partisipasi adalah proses bersama saling memahami, menganalisis, merencanakan, dan melakukan tindakan oleh sejumlah anggota. Sedangkan menurut Yoland Wadworth, PAR adalah istilah yang memuat seperangkat asumsi yang mendasari paradigma baru ilmu pengetahuan dan bertentangan dengan paradigma pengetahuan tradisional atau kuno. Asumsi asumsi baru tersebut menggaris bawahi arti penting proses sosial dan kolektif dalam mencapai kesimpulan kesimpulan mengenai "apa kasus yang sedang terjadi" dan "apa implikasi perubahannya" yang dipandang berguna oleh orang orang yang berada pada situasi problematis, dalam mengantarkan untuk penelitian awal. Dari beberapa teori di atas dapat ditarik kesimpulan bahwasannya penelitian Participatory Active Research (PAR) yaitu penelitian yang mana melibatkan peneliti dan orang-orang yang terlibat untuk dapat mengambil manfaat dari proses penelitian yang ada serta berkontribusi penuh selama penelitian berlangsung. Teknik pengumpulan data yang digunakan pengabdi yaitu observasi dan dokumentasi.

\section{HASIL DAN PEMBAHASAN}

Dari data yang pengabdi dapatkan dari lapangan, maka hasil dan pembahasan ini dapat dikategorikan beberapa hal diantaranya sebagai berikut:

1. Pelaksanaan Pendampingan Pembelajaran Baca Tulis Al-Qur'an Di TPQ Raudlatul Abror Dusun Tomporejo, Desa Dengkol, Kecamatan Singosari

Seyogyanya, pembelajaran BTQ atau biasa disebut sebagai baca tulis Qur'an di TPQ Roudlotul Abror yaitu dengan menggunakan metode Iqro' dimana dalam penerapannya terbagi menjadi 6 jenjang. Metode ini digunakan dalam upaya untuk meningkatkan kualitas baca tulis Al-Qur'an para santri. Teknik pengajaran Iqro' pada TPQ Roudlotul Abror yaitu dengan menggunakan metode privat yang mana santri satu persatu maju ke depan ustadz/ustadzah. Selepas membaca Iqro' satu persatu, santri selanjutnya menulis huruf Hijaiyah sesuai dengan yang sudah dituliskan oleh 
ustadz/ustadzah yang mana setelah itu dibacakan secara bersama-sama serta tugas menulis huruf Hijaiyah tersebut dikumpulkan ke ustadz/ustadzah untuk dikoreksi dan ditunjang ulang bagian mana saja yang perlu diperbaiki cara penulisannya agar santri bisa lebih memahami tata cara penulisan huruf Hijaiyah yang baik dan benar. Hal menarik lainnya saat pelaksanaan pembelajaran BTQ para santri juga diajarkan mata pelajaran seperti Matematika atau lebih tepatnya penjumlahan dan pengurangan bagi Iqro'1 -3 serta pembagian dan perkalian bagi Iqro' 4-6 dan juga ilmu agama seperti fiqih, kitab kuning dan Bahasa Arab bagi kelas tinggi. Pendampingan ini dilakukan selama 4 minggu dimana pada minggu pertama kelompok KSM Tematik 11 melakukan observasi proses pembelajaran yang terdapat di TPQ Roudlotul Abror. Kemudian, di minggu kedua sampai minggu keempat peserta KSM Tematik Kelompok 11 yang mana terdapat gabungan kelompok kecil dari kelompok 11 dan 32 mendampingi para santri untuk melaksanakan proses pembelajaran BTQ yang berlangsung di Roudlotul Abror.

\section{Faktor Pendukung dan Penghambat Proses Pembelajaran Baca Tulis Al-Qur'an Di TPQ Raudlatul Abror Dusun Tomporejo, Desa Dengkol, Kecamatan Singosari}

Selama proses pembelajaran baca tulis Al-Qur'an di TPQ Raudlatul Abror terdapat faktor pendukung yang mendorong proses meningkatkan kualitas baca tulis AlQur'an di TPQ Raudlatul Abror yaitu meliputi: (a) Fasilitas yang terdapat di TPQ sangat memadai seperti : meja kecil untuk masing-masing peserta didik, papan tulis hitam dan kapur tulis, kipas angin, karpet tempat peserta didik duduk, dan alat pengeras suara jika sewaktu-waktu diperlukan; (b) Kondisi ustadz dan ustadzah atau tenaga pendidik di TPQ Raudlatul Abror sudah mempunyai bekal pendidikan yang baik; (c) Metode pembelajaran baca tulis Al-Qur'an yang dipakai di TPQ Raudlatul Abror yaitu metode ummi, yang mana metode ini sangat menyesuaikan dengan anak-anak yang berbedabeda umurnya, metode yang sederhana dan memudahkan para peserta didik dalam belajar; (d) Keaktifan para peserta didik saat masuk mengaji merupakan faktor pendukung yan bisa mempercepat kualitas pemahaman dan kemampuan peserta didik terhadap baca tulis Al-Qur'an; (e) Lingkungan yang kondusif yaitu merupakan sebuah dukungan dan dorongan dari masyarakat sekitar yang pada akhirnya bisa berdiri TPQ Rudlatul Abror ini ditengah-tengah pemukiman warga, walaupun tempatnya tidak terlalu luas namun nyaman; (f) Durasi waktu pembelajaran di TPQ Raudlatul Abror yaitu 180 menit atau 3 jam, yaitu 90 menit untuk kelas rendah dan 90 menit untuk kelas atas.

Sedangkan untuk faktor penghambat dalam meningkatkan kualitas baca tulis AlQur'an di TPQ Raudlatul Abror yaitu: (a) Kondisi ustadz dan ustadzah atau tenaga pendidik selalu dijadikan fakus dalam proses terjadinya pembelajaran, di TPQ Raudlatu Abror jumlah ustadz dan ustadzah kurang sepadan dengan jumlah kelas dan banyaknya peserta didik yang ada, sehingga terkadang sering kuwalahan dan tidak bisa benarbenar focus dalam mengawasi setiap peserta didik; (b) Untuk kelas rendah peserta didik di damping oleh wali murid, sehingga saat proses pembelajaran berlangsung wali murid masih ikut campur atas tugas anaknya. Bahkan seringkali saat ustadz atau ustadzah meminta peserta didik untuk menulis materi di papan tulis, wali muridlah yang menuliskannya dengan alasan anaknya belum terlalu bisa menulis, sehingga takut diberi nilai yang kurang bagus oleh ustadz atau ustadzahnya; (c) Terdapat banyakya peserta didik yang sering membolos dan tanpa alasan yang jelas, karena tidak ada ketegasan baik dari ustadz dan ustadzahnya ataupun dari pengasuh TPQ sendiri. Bahwasannya tidak ada sanksi untuk peserta didik yang tidak masuk tanpa alas an; (d) Kurangnya strategi yang digunakan saat proses pembelajaran baca tulis Al-Qur'an, penggunaan metode ummi memang sangat mudah dan sederhana tetapi dalam proses penyampaiannya juga 
harus diperkaya agar peserta didik tidak mudah merasa bosan. TPQ Raudlatul Abror terus berbenah dari banyaknya kekurangan yang ada dan factor penghambat yang terjadi.

\section{KESIMPULAN}

Dapat ditarik keimpulan dari hasil pengabdian yang dilakukan diantaranya sebagai berikut: (1) Proses pendampingan pembelajaran BTQ di TPQ Roudlotul Abror yaitu dengan menggunakan metode Iqro' dimana dalam penerapannya terbagi menjadi 6 jenjang. Teknik pengajaran Iqro' pada TPQ Roudlotul Abror yaitu dengan menggunakan metode privat yang mana santri satu persatu maju ke depan ustadz/ustadzah, (2) Faktor pendukung untuk meningkatkan kualitas baca tulis Al-Qur'an peserta didik di TPQ Raudlatul Abror Dusun Tomporejo, Desa Dengkol, kecamatan Singosari meliputi : fasilitas yang memadai, kualitas tenaga pendidik yang sudah mempunyai bekal pendidikan yang baik, metode pembelajaran ummi yang memudahkan, kondisi lingkungan yang kondusif atas dorongan dan dukungan kepada TPQ, serta alokasi waktu yang cukup pada saat pembelajaran berlangsung. Sedangkan factor penghambatnya meliputi: kurangnya jumlah tenaga pendidiknya, kurang tegasnya tenaga pendidik kepada wali murid yang terkadang menganggu proses pembelajaran berlangsung, tidak adanya sanksi bagi peserta didik yang sering membolos tanpa alasan, serta kurang kayanya metode pembelajaran yang digunakan.

\section{DAFTAR RUJUKAN}

Arifin, Z., \& Tamrin, T. (2019). Peningkatan Kompetensi Microcontroller Siswa SMK. Jurnal Inovasi Hasil Pengabdian Masyarakat (JIPEMAS), 2(1), 49-53. https://doi.org/10.33474/jipemas.v2i1.1772

Aristanto, E., Hidayatullah, S., Rachmawati, I. K., Waris, A., \& Khalikussabir. (2020). Peningkatan Fasilitas Bagi Tahfizh Anak Usia Dini "Kuttab Rumah Quran" Menuju Persaingan Pendidikan Anak Pra Sekolah. Jurnal Inovasi Hasil Pengabdian Masyarakat (JIPEMAS), 3(1), 78-86. https://doi.org/10.33474/jipemas.v3i1.4763

Gagne, R. M. (1977). Conditions of Learning (3rd Editio). Thomson Learning.

Malik, H. A. (2013). Pemberdayaan Taman Pendidikan Al-Qur'an (TPQ) ALhusna Pasadena Semarang. Dimas: Jurnal Pemikiran Agama Untuk Pemberdayaan, 13(2), 387-404. https://doi.org/10.21580/dms.2013.132.60

Muntoha, Jamroni, Khoiruzaad, M., Prasetyo, H., Wijaya, M. A., Jabbar, A. A., U., R. U., A.W., D. A., P, D. I., \& Tantria, H. (2015). Pembinaan Taman Pendidikan Al-Qur'an (TPA) di Dusun Sangbanyu 1, Kecamatan Giri Subo, Gunung Kidul, Daerah Istimewa Yogyakarta. Jurnal Inovasi Dan Kewirausahaan, 4(3), 200-205.

Suhartoyo, E., Wailissa, S. A., Jalarwati, S., Samsia, S., Wati, S., Qomariah, N., Dayanti, E., Maulani, I., Mukhlish, I., Rizki Azhari, M. H., Muhammad Isa, H., \& Maulana Amin, I. (2020). Pembelajaran Kontekstual Dalam Mewujudkan Merdeka Belajar. Jurnal Pembelajaran Pemberdayaan Masyarakat (JP2M), 1(3), 161-164. https://doi.org/10.33474/jp2m.v1i3.6588

Suyitno. (2018). Peranan Taman Pendidikan Al-Qur'an (TPA) dalam Pendidikan Karakter. Edukasi: Jurnal Penelitian Dan Artikel Pendidikan, $\quad x x(\mathrm{xx}), \quad 9-16$. https://doi.org/10.31603/edukasi.v0i0.2352

Zakaria, Z., Setyosari, P., Sulton, \& Kuswandi, D. (2019). The effect of art-based learning to improve teaching effectiveness in pre-service teachers. Journal for the Education of Gifted Young Scientists, 7(3), 531-545. https://doi.org/10.17478/jegys.606963 